\title{
Fluxing of South African chromite ore with colemanite
}

\author{
by M.W. Erwee, I.J. Geldenhuys, M.B. Sitefane, and M. Masipa
}

\section{Synopsis}

South African chromite ores are smelted using $\mathrm{SiO}_{2}$ - and $\mathrm{CaO}$-containing fluxes, normally as quartz and limestone respectively. The purpose of $\mathrm{SiO}_{2}$ is to lower the melting point of the ore, while $\mathrm{CaO}$ is added to ensure that the slag that forms on smelting is fluid enough to enable slag/alloy separation and tapping from the furnace. Colemanite is a borate mineral originating primarily from Turkey, and has the nominal, ideal composition $\mathrm{CaB}_{3} \mathrm{O}_{4}(\mathrm{OH})_{3} \cdot \mathrm{H}_{2} \mathrm{O} \cdot \mathrm{B}_{2} \mathrm{O}_{3}$ readily fluxes chromite, and low amounts of this compound can yield a lowering of the melting temperature similar to that obtained using $\mathrm{SiO}_{2}$. In addition, colemanite already contains $\mathrm{CaO}$, which aids in making the resulting slag more fluid.

Laboratory-scale smelting tests were conducted at Mintek over the course of 18 months. The work included evaluation of a variety of boroncontaining materials to replace conventional fluxes. The results of the tests and modelling work are presented in this paper.

\section{Keywords}

chromite, smelting, ferrochrome, colemanite, boron, energy.

\section{Introduction}

The BOFLUX project was an initiative launched by Mintek and two other partners (see acknowledgements) in response to the second ERA-MIN joint call in 2014 on sustainable supply of raw materials in Europe. At the time, both chromium and borate minerals were on the 2014 EU critical raw materials list (European Commission, 2014). In this document, it was stated that South Africa held $80 \%$ of the world's chromite resources, while Turkey held $98 \%$ of the world's borate minerals.

The project was based on the premise that several process improvements to chromite smelting would be possible using borate minerals as fluxes in place of conventional fluxes. The improvements envisaged were lower impurity levels (higher $\mathrm{Cr}$ grade), reduced operating temperatures, reduced flux consumption, reduced slag to metal ratios, and lower energy consumption. Similar work on laboratory and industrial scales has been conducted in, inter alia, Kazakhstan in the production of ferrosilicon and ferrosilicochrome (Akberdin et al., 2013). This prompted an investigation into whether similar benefits were possible for South African chromite smelting operations, starting with fundamental and laboratory-scale research, the results of which could be used as a guideline for further work.

In this paper, conventional fluxing of chromite ore in South African operations is discussed to set the scene, followed by the principles behind fluxing with borates, in this case, specifically colemanite. Results from laboratory-scale tests done at Mintek, in which conventional fluxes were tested against borates, then follow.

\section{Conventional smelting of chromite in South Africa}

\section{Chromite sources and smelting operations in South Africa}

Chromite ores in South Africa originate mainly from the Bushveld Complex. Broadly, the MG1, MG2, and LG6 seams in the Complex are mined to produce feed for chromite smelting, while the UG2 Reef is mined as a source of platinum group metals (PGMs). The 'discard' streams from UG2 ore processing have become a valuable raw material for ferrochrome producers, as was predicted some 14 years ago (Cramer, Basson, and Nelson, 2004).

The composition of chromite varies substantially, and a comprehensive overview of each ore or concentrate is beyond the scope of this paper. The typical compositions of some South African chromite ores are given in Table I (Geldenhuys, 2013).

It is very important to point out that ores listed in Table I are just a few examples of what is used by the industry. Several smelting operations rely on various other chromite sources with varying $\mathrm{Cr}_{2} \mathrm{O}_{3}$ contents, $\mathrm{Cr} / \mathrm{Fe}$ ratios, and gangue mineral content.

* Mintek, South Africa.

(c) The Southern African Institute of Mining and Metallurgy, 2018. ISSN 2225-6253. This paper was first presented at the INFACON XV: International Ferro-Alloys Congress, 25-28 February 2018, Century City Conference Centre and Hotel, Cape Town, South Africa 


\section{Fluxing of South African chromite ore with colemanite}

\begin{tabular}{|c|c|c|c|c|c|c|}
\hline $\begin{array}{l}\text { Typi } \\
\text { (maj } \\
2013\end{array}$ & $\begin{array}{l}\text { comp } \\
\text { compc }\end{array}$ & $\begin{array}{l}\text { ition } \\
\text { ints I }\end{array}$ & d, m & $\begin{array}{l}\text { fricar } \\
\% \text { ) }\end{array}$ & $\begin{array}{l}\text { Irom } \\
\text { Ident }\end{array}$ & \\
\hline Origin & $\mathrm{Cr}_{2} \mathrm{O}_{3}$ & $\mathrm{FeO}$ & $\mathrm{MgO}$ & $\mathrm{Al}_{2} \mathrm{O}_{3}$ & $\mathrm{SiO}_{2}$ & $\mathrm{Cr} / \mathrm{Fe}$ \\
\hline LG6 & 46.6 & 25.0 & 10.8 & 15.1 & 0.6 & 1.6 \\
\hline & 42.6 & 27.4 & 9.3 & 14.9 & 1.2 & 1.4 \\
\hline MG & 42.9 & 28.5 & 8.8 & 15.7 & 3.0 & 1.3 \\
\hline
\end{tabular}

South African chromite ores and concentrates are blended to obtain a $\mathrm{Cr} / \mathrm{Fe}$ ratio that is high enough to produce "charge chrome', a special grade of high-carbon ferrochrome ( $\mathrm{HCFeCr}$ ). Charge chrome contains approximately $50-53 \% \mathrm{Cr}$, 6-8\% C, 4-6\% Si, and the balance Fe, with minor impurities such as $\mathrm{S}$ and $\mathrm{P}$ (Gasik, 2013).

Not all ferrochrome in South Africa is produced via the submerged arc furnace (SAF) route. Some $8-10 \%$ of other ferrochrome products (e.g. plasma chrome, a low-carbon $\mathrm{FeCr}$ alloy) is produced using DC furnace technology.

The type of furnace, operating temperature, and slag chemistry are all factors that affect the recovery of $\mathrm{Cr}$ from chromite and hence the quality of the final product. The $\mathrm{Cr} / \mathrm{Fe}$ ratio of the ore largely determines the $\mathrm{Cr}$ content of the product from a particular furnace. Typical figures for chrome recoveries in various furnaces are given in Table II (Gasik, 2013). The energy required for smelting is also given $(\mathrm{kWh} / \mathrm{t}$ FeCr product).

The chromite feed material is often pelletized and then either prereduced or sintered before it is charged to a SAF. A broad outline of process operations for ferrochrome production in South Africa is given in Figure 1. Note, that it is no longer common for most producers to use lumpy ore as primary feed material.

\section{Fundamentals of fluxing in conventional ferrochrome production}

Chromite ore contains a mixture of complex spinel minerals and pyroxenes. Most of the chrome and iron in chromite is present as $(\mathrm{Fe}, \mathrm{Mg})(\mathrm{Cr}, \mathrm{Al})_{2} \mathrm{O}_{4}$ spinel. A graphical representation of the spinel structure is given in Figure 2. After processed through a beneficiation plant, the ore concentrate consists of up to $95 \%$ spinel.

If, for example, the composition of the ore is expressed as a mixture of ideal spinel minerals, the LG6 type ore composition could be recalculated to be approximately $21.3 \%$ $\mathrm{MgAl}_{2} \mathrm{O}_{4}, 23.3 \% \mathrm{MgCr}_{2} \mathrm{O}_{4}, 42.2 \% \mathrm{FeCr}_{2} \mathrm{O}_{4}, 12.6 \% \mathrm{Fe}_{3} \mathrm{O}_{4}$, and $0.6 \% \mathrm{SiO}_{2}$.

The purpose of smelting is to reduce most of the $\mathrm{Cr}_{2} \mathrm{O}_{3}$ in the $\mathrm{MgCr}_{2} \mathrm{O}_{4}$ and $\mathrm{FeCr}_{2} \mathrm{O}_{4}$ spinel phases to $\mathrm{Cr}$ and separate it from the main gangue components, $\mathrm{MgO}, \mathrm{Al}_{2} \mathrm{O}_{3}$, and $\mathrm{SiO}_{2}$, which form a slag phase.

Reduction of chrome spinel occurs both directly and indirectly in different parts of the furnace. This process is complex and is very well described by Hayes (2004). Simplified, the overall reactions for reduction of chrome and iron oxide in the chrome spinel by carbon are:

$$
\mathrm{FeCr}_{2} \mathrm{O}_{4}+4 \mathrm{C} \rightarrow \mathrm{Fe}+2 \mathrm{Cr}+4 \mathrm{CO}
$$

$$
\mathrm{MgCr}_{2} \mathrm{O}_{4}+3 \mathrm{C} \rightarrow \mathrm{MgO}+2 \mathrm{Cr}+3 \mathrm{CO}
$$

As a side reaction, due to process temperatures between $1700^{\circ} \mathrm{C}$ and $1750^{\circ} \mathrm{C}$, some $\mathrm{SiO}_{2}$ is reduced to $\mathrm{Si}$, which dissolves into the alloy:

$$
\mathrm{SiO}_{2}+2 \mathrm{C} \rightarrow \mathrm{Si}+2 \mathrm{CO}
$$

Inevitably, reduction of $\mathrm{Fe}^{2+}$ and $\mathrm{Fe}^{3+}$ in the ore will occur at the typical smelting temperatures of above $1650^{\circ} \mathrm{C}$ and hence dilute the final FeCr product with Fe. Further dilution of the product takes place by reduction of the limited amount of iron oxides in the reductant as well as reduction of $\mathrm{SiO}_{2}$ from ore, reductant, and fluxes to $\mathrm{Si}$.

\section{Table II \\ Chrome recovery and energy consumption for different furnaces used for $\mathrm{FeCr}$ production, partially adapted from (Gasik, 2013) and personal communication with producers}

\begin{tabular}{|l|c|c|}
\hline Type of furnace & Chrome recovery & SEC* (kWh/t) \\
\hline $\begin{array}{l}\text { Open AC furnace (without raw } \\
\text { material screening) }\end{array}$ & $70-75 \%$ & $4000-4300$ \\
$\begin{array}{l}\text { Closed AC furnace (with pelletized } \\
\text { feed and preheating) }\end{array}$ & $83-88 \%$ & $3100-3400$ \\
$\begin{array}{l}\text { Prereduction followed by closed } \\
\text { AC furnace } \\
\text { Closed DC furnace }\end{array}$ & $88-92 \%$ & $2400^{* *}$ \\
\hline
\end{tabular}

*SEC: Specific energy consumption

**Electrical energy consumed, i.e. excludes energy required for burning fuel in the prereduction kiln

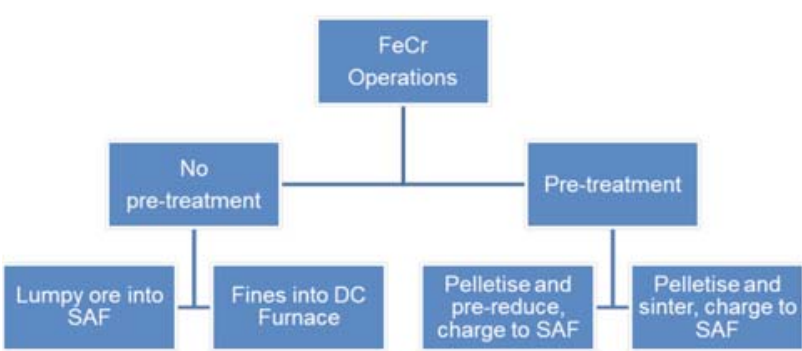

Figure 1-Broad categories of FeCr smelting operations in South Africa

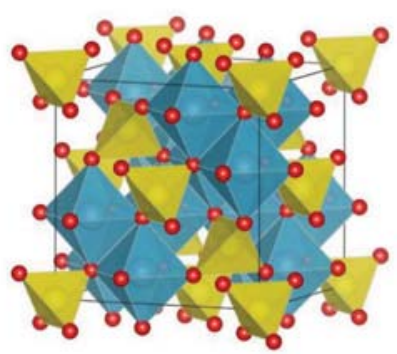

Figure 2-A graphical representation of a complex spinel phase (crystallography365.wordpress.com). In general, spinel can be represented as $\mathrm{AB}_{2} \mathrm{O}_{4}$. Yellow tetrahedra represent $\mathrm{A}$; blue octahedra, $B$; red, oxygen anions 


\section{Fluxing of South African chromite ore with colemanite}

The nature of spinel is such that removal of oxygen from the structure causes a charge imbalance, which is restored by migration of cations to vacancies created during reduction. For example: when $\mathrm{Cr}^{3}+$ is reduced to $\mathrm{Cr} 2+$ ions that migrate to the outer parts of an ore particle, it is replaced by Al3+. In turn, for example, stable $\mathrm{MgAl}_{2} \mathrm{O}_{4}$ would form in the structure, which needs to be fluxed to facilitate separation between metal and slag. This mechanism is well described by, inter alia, Hayes (2004).

To reduce the melting point (liquidus temperature) of the gangue material, $\mathrm{SiO}_{2}$ is added to the furnace as quartz flux, which dissolves the $\mathrm{MgAl}_{2} \mathrm{O}_{4}$ spinel and dilutes other gangue minerals, namely $\mathrm{SiO}_{2}, \mathrm{CaO}$, etc.

On an isothermal projection of the $\mathrm{SiO}_{2}-\mathrm{MgO}-\mathrm{Al}_{2} \mathrm{O}_{3}$ phase diagram at $1650^{\circ} \mathrm{C}$ (Figure 3 ) it is easy to see that the gangue in typical South African ores is not fully molten. The melting points of the gangue components of MG, LG6, and UG2 ores are $2014^{\circ} \mathrm{C}, 1987^{\circ} \mathrm{C}$, and $2008^{\circ} \mathrm{C}$ respectively. Fluxing with even a limited amount of $\mathrm{SiO}_{2}$ reduces the melting point significantly to 1650 to $1750^{\circ} \mathrm{C}$, but the slag then contains $35-40 \% \mathrm{SiO}_{2}$ and is quite viscous.

A basic oxide, $\mathrm{CaO}$, is added to lower the viscosity of the slag. In many operations, CaO levels of between 10 and 15\% are maintained to ensure that the slag is sufficiently fluid for tapping.

Aside from in tapping, the fluidity of the slag is extremely important since it determines the rate of settling of alloy droplets through the slag, and thus the efficiency of alloy/slag separation. Furthermore, slags with higher $\mathrm{CaO} / \mathrm{SiO}_{2}$ ratios are known to yield better chrome recoveries (Holappa and Xiao, 2004). In addition, higher amounts of $\mathrm{CaO}$ in the slag lead to lower $\mathrm{SiO}_{2}$ activities, which in turn keep Si levels in the metal lower than with low-CaO slags.

Somewhat counterintuitively, the addition of $\mathrm{CaO}$ to the slag results in a slight increase in liquidus temperature, but for South African chromite smelting slags the effect of $\mathrm{CaO}$ on the viscosity of the slag is greater than the increase in liquidus temperature (Jones and Erwee, 2016).

Typical furnace operating temperatures in South African smelters are between $1700^{\circ} \mathrm{C}$ and $1750^{\circ} \mathrm{C}$, which is close to the liquidus temperature of the slag. This is not accidental,

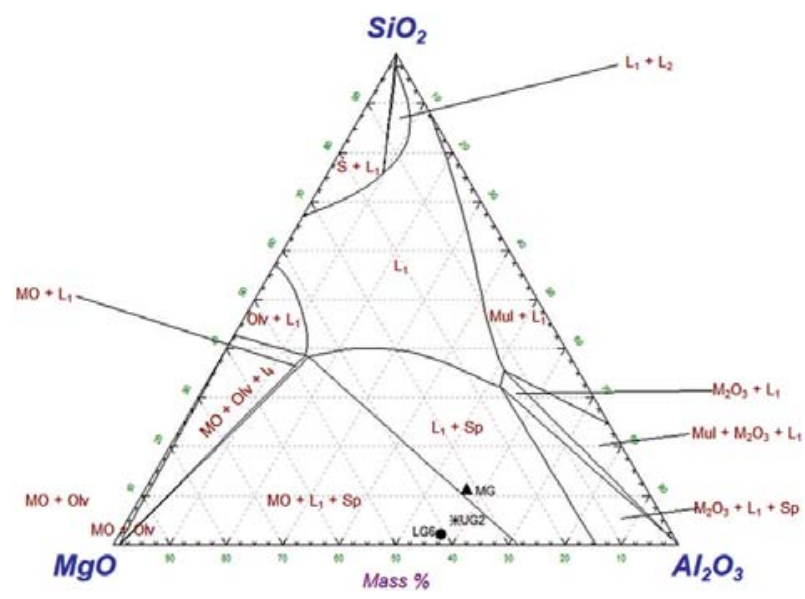

Figure 3-Isothermal projection of the $\mathrm{SiO}_{2}-\mathrm{MgO}-\mathrm{Al}_{2} \mathrm{O}_{3}$ system at $1650^{\circ} \mathrm{C}$ (drawn in FactSage 7.1). $\mathrm{Sp}=$ spinel, $\mathrm{MO}=$ monoxide (MgO), $\mathrm{S}=\mathrm{SiO}_{2}, \mathrm{M}_{2} \mathrm{O}_{3}=$ corundum, $\mathrm{L}=$ liquid, Olv = olivine) and significant effort goes into choosing the correct fluxing regime for a specific ore mixture. The composition of the slag is designed deliberately such that its liquidus is $100-150^{\circ} \mathrm{C}$ higher than that of the alloy (Jones and Erwee, 2016), which melts between 1520 and $1580^{\circ} \mathrm{C}$.

\section{Colemanite as a possible flux for ferrochrome production}

Borate minerals have been suggested as an alternative to $\mathrm{SiO}_{2}$ as flux and $\mathrm{CaO}$ as slag modifier in chromite smelting. Colemanite can be approximated by the formula $2 \mathrm{CaO} .3 \mathrm{~B}_{2} \mathrm{O}_{3} .5 \mathrm{H}_{2} \mathrm{O}$. Crystal water is released from pure colemanite at temperatures above approximately $400^{\circ} \mathrm{C}$, leaving behind $\mathrm{CaO}$ and $\mathrm{B}_{2} \mathrm{O}_{3}$, which melts at approximately $930^{\circ} \mathrm{C}$. Colemanite ores, however, also contain some impurities such as $\mathrm{S}, \mathrm{SiO}_{2}, \mathrm{Al}_{2} \mathrm{O}_{3}$, and $\mathrm{MgO}$.

$\mathrm{B}_{2} \mathrm{O}_{3}$ is a very strong flux for gangue in chromite ores $\left(\mathrm{MgO}\right.$ and $\mathrm{Al}_{2} \mathrm{O}_{3}$ ). This is quite evident if one considers Figure 4.

Figure 4 was calculated with FactSage 7.1 using the FTOxid database for molten oxides. The thick black line is the isothermal projection at $1750^{\circ} \mathrm{C}$ for the chromite ore and gangue mixture without any $\mathrm{B}_{2} \mathrm{O}_{3}$ added. Comparing this with the liquidus region of $1650^{\circ} \mathrm{C}$ (blue line), it is easy to see that significantly less $\mathrm{SiO}_{2}$ is required to reduce the melting point of the gangue for typical furnace operating temperatures. Aside from the lower $\mathrm{SiO}_{2}$ content, a slag at $1750^{\circ} \mathrm{C}$ would be significantly less viscous (typically 1.5 poise) than a slag at $1650^{\circ} \mathrm{C}$.

However, what is also evident in Figure 4 is that only $10 \% \mathrm{~B}_{2} \mathrm{O}_{3}$ in the $\mathrm{SiO}_{2}-\mathrm{MgO}-\mathrm{Al}_{2} \mathrm{O}_{3}$ system leads to significantly larger liquidus regions at $1650^{\circ} \mathrm{C}$ and $1750^{\circ} \mathrm{C}$, as indicated by the dotted lines in the diagram. In fact, at levels as low as $10 \% \mathrm{~B}_{2} \mathrm{O}_{3}$, the liquidus region at $1650^{\circ} \mathrm{C}$ is even larger than the liquidus region at $1750^{\circ} \mathrm{C}$ when no $\mathrm{B}_{2} \mathrm{O}_{3}$ is present.

As a simplified example, consider the composition of the gangue mixture for a typical LG6 ore (see Table I). The calculated effect of adding either pure $\mathrm{CaO}, \mathrm{SiO}_{2}, \mathrm{~B}_{2} \mathrm{O}_{3}$, or pure colemanite $\left(2 \mathrm{CaO} .3 \mathrm{~B}_{2} \mathrm{O}_{3} .5 \mathrm{H}_{2} \mathrm{O}\right)$ to this gangue mixture is shown in Figure 5.

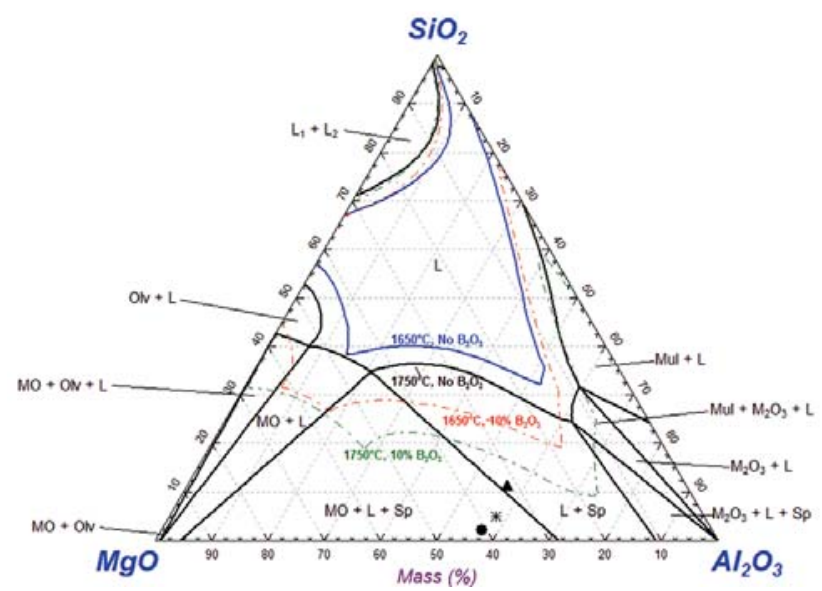

Figure 4-Polythermal projections of the $\mathrm{SiO}_{2}-\mathrm{MgO}-\mathrm{Al}_{2} \mathrm{O}_{3}-\mathrm{B}_{2} \mathrm{O}_{3}$ system at 1650 and $1750^{\circ} \mathrm{C}$ (drawn using FactSage 7.1, symbols have the same meaning as in Figure 3) 


\section{Fluxing of South African chromite ore with colemanite}

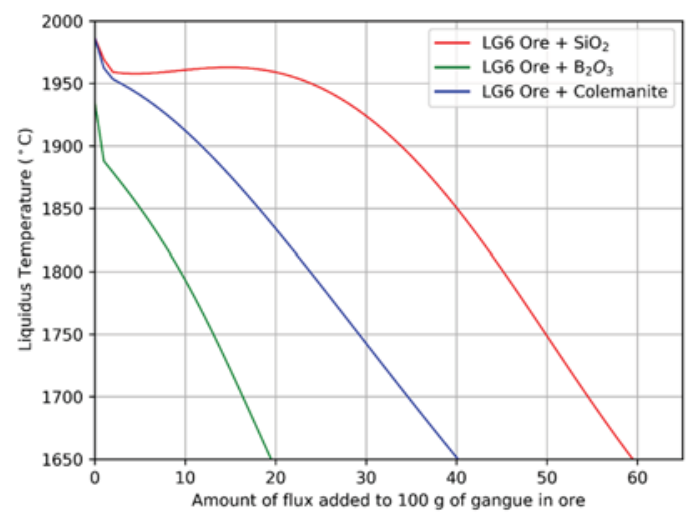

Figure 5-Effect of fluxes on melting point of an ore-gangue mixture of initial composition: $57 \% \mathrm{Al}_{2} \mathrm{O}_{3}, 41 \% \mathrm{MgO}$, and $2 \% \mathrm{SiO}_{2}$

From Figure 5, it is clear that to reach a liquidus temperature of approximately $1650^{\circ} \mathrm{C}$, the required amount of $\mathrm{B}_{2} \mathrm{O}_{3}$ is almost one-third of the amount of $\mathrm{SiO}_{2}$ that would be required. Interestingly, but not surprisingly, the amount of colemanite required is between that of pure $\mathrm{SiO}_{2}$ and $\mathrm{B}_{2} \mathrm{O}_{3}$. The reason for this is that colemanite, in addition to $\mathrm{B}_{2} \mathrm{O}_{3}$, contains $\mathrm{CaO}$, which raises the melting point of an $\mathrm{MgO}$ $\mathrm{Al}_{2} \mathrm{O}_{3}-\mathrm{SiO}_{2}$ mixture. However, the $\mathrm{CaO}$ component aids in reducing the viscosity of the resulting slag (see Figure 6).

There is however, a caveat to using colemanite as a flux for chromite smelting. Unlike $\mathrm{SiO}_{2}$, which is thermodynamically more difficult to reduce with carbon in comparison with $\mathrm{Cr}_{2} \mathrm{O}_{3}$ and $\mathrm{FeO}_{\mathrm{x}}$ during smelting, $\mathrm{B}_{2} \mathrm{O}_{3}$ is almost as easy to reduce as $\mathrm{Cr}_{2} \mathrm{O}_{3}$ and $\mathrm{CrO}$ in slag, as seen on a modified Ellingham-Richardson type diagram (Figure 7).

Solid lines represent reaction $\mathrm{M}+\mathrm{O}_{2}$ ? $\mathrm{MO}_{2}$ for all compounds at unit activity, while corresponding dashed lines represent the same reactions but at non-standard activity. Ranges for activity values are based on thermodynamic simulations described later in this paper $(\mathrm{M}=\mathrm{Cr}, \mathrm{Si}, \mathrm{B}$, and C). It is important to also mention that the reduction of $\mathrm{B}_{2} \mathrm{O}_{3}$ to volatile $\mathrm{B}_{2} \mathrm{O}_{2}$ gas is also possible at higher temperatures, which is not shown on this diagram, nor are any reactions involving borides, carbides, or carbo-borides. However, in a simple way, what should be apparent from the diagram is that $\mathrm{CrO}, \mathrm{Cr}_{2} \mathrm{O}_{3}, \mathrm{SiO}_{2}$, and $\mathrm{B}_{2} \mathrm{O}_{3}$ all compete for carbon $\left(\mathrm{FeO}_{\mathrm{x}}\right.$ not included).

Aside from contaminating the final product, $\mathrm{B}_{2} \mathrm{O}_{3}$ reduction will consume excess reductant and also remove $\mathrm{B}_{2} \mathrm{O}_{3}$ from the slag, making the fluxing effect less effective.

\section{The potential impact of colemanite as flux}

The use of colemanite flux was expected to lower the energy requirement for smelting since it would reduce smelting temperatures to $1650^{\circ} \mathrm{C}$, decrease the amount of $\mathrm{Si}$ in the alloy (which is typically between 4-6\%), which in turn would lead to a higher grade of $\mathrm{Cr}$; and lower slag volumes, which could lead to increased throughput in the furnace. In addition, it was anticipated that lower losses of alloy by entrainment in the slag would occur due to lower slag viscosity. However, the potential benefits of using colemanite as flux must be offset against the cost.

\section{Energy consumption and cost of production for chromite smelting}

Whereas other countries such as India, Kazakhstan, Finland, China, and Turkey have increased their production of $\mathrm{FeCr}$ over the last 3 years, the production of FeCr in South Africa

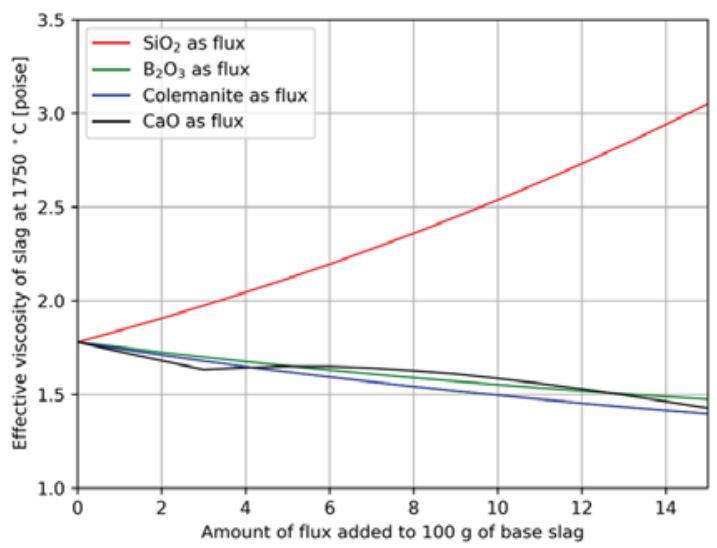

Figure 6-Effect of various fluxes on the viscosity of a chromite smelting slag based on LG6 gangue minerals (calculated using FactSage 7.1)

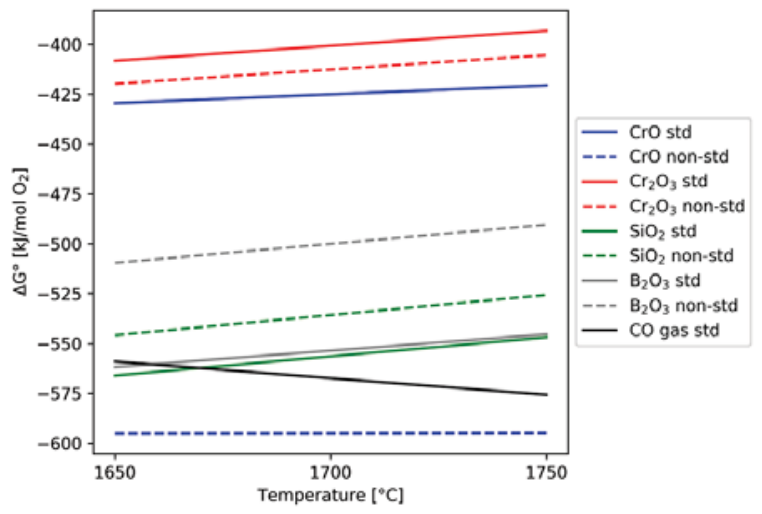

Figure 7-Free energy change of reactions between various compounds with 1 mole of $\mathrm{O}_{2}$

\begin{tabular}{|c|c|c|}
\hline \multicolumn{3}{|c|}{$\begin{array}{l}\text { Table III } \\
\text { Cost of production of FeCr in South Africa, } 2016 \\
\text { (Pariser, 2017) }\end{array}$} \\
\hline $\begin{array}{l}\text { Exchange rate, R/US\$ } \\
\% \mathrm{Cr} \text { in } \mathrm{FeCr}\end{array}$ & $\begin{array}{c}14.71 \\
49.6\end{array}$ & \\
\hline Variable costs & Cost (US cents / lb Cr) & $\%$ of total \\
\hline $\begin{array}{l}\text { Raw materials } \\
\text { Chromite ore } \\
\text { Reductants } \\
\text { Others }^{1} \text { (fluxes, electrode paste) } \\
\text { Energy } \\
\text { Operating costs } \\
\text { Semi-fixed costs } \\
\text { Labour } \\
\text { G\&A, maintenance } \\
\text { Total direct cash production cost }\end{array}$ & $\begin{array}{c}13.87 \\
7.31 \\
1.46 \\
18.15 \\
1.69\end{array}$ & $\begin{array}{c}29.1 \\
15.3 \\
3.1 \\
38.1 \\
3.5\end{array}$ \\
\hline
\end{tabular}

1Ex-works 


\section{Fluxing of South African chromite ore with colemanite}

has declined from approximately $3.774 \mathrm{Mt} / \mathrm{a}$ in 2014 to $3.596 \mathrm{Mt} / \mathrm{a}$. Among the most important reasons cited for this is the high cost of electricity. The electricity price in South Africa has almost quadrupled over the last decade (Pariser, 2017).

The direct cash production cost of FeCr in South Africa comprises three main elements: electricity, chromite ore, and reductants. All other costs (labour, maintenance, electrode paste, fluxes, etc.) make up a relatively minor portion (15\%) of this cost.

It is clear that the largest operating cost in the $\mathrm{FeCr}$ production process in South Africa is electricity - in 2016 it was a staggering $38.1 \%$ of the total production cost. The cost of fluxes and electrode paste is a mere $3.1 \%$; however, fluxes can play an important role in lowering the energy requirement for smelting.

An extensive review of a $\mathrm{FeCr}$ furnace energy balance was done by Ringdalen (2015). That work (and similar calculations at Mintek) established that the majority (approx. $75 \%$ of the total) of the energy consumed in a furnace is at temperatures above $1200^{\circ} \mathrm{C}$, where reduction of chromite and melting of both gangue and metal occur inside the coke bed.

of particular importance is the effect of different parameters on the overall energy requirement of the furnace. A selected few are shown in Table IV.

With the overall energy requirement for smelting between 3.5 to $4.0 \mathrm{MWh} / \mathrm{t}$, the savings might seem marginal, but if a combination of savings can be achieved, then a worthwhile benefit can be realized.

\section{Thermodynamic modelling and parameter space search}

Thermodynamic modelling was done to help guide test work for this project. The modelling was done using FactSage ${ }^{\mathrm{TM}} 7.1$ (Bale, 2016). Databases used were FTOxid (for oxide solutions, including slag), SGTE (for the resulting alloy phase), and FactPS (for gases, pure oxides, and pure elements). Models were implemented using ChemApp v 6.4.5 via the ChemAppForPy API (version 0.1.4). ChemApp is a free-energy minimization module and is also the backbone to the 'Equilib' module of FactSage, hence the two are used interchangeably as they yield the same result. Free-energy minimization is a method used to determine the composition of a combination of multiple species at specific conditions (in this case temperature and pressure) that minimize the total Gibbs free energy of the system. Several thousand permutations were considered using the thermodynamic model.
The optimal level of flux would be such that:

> The smelting temperature can be lowered to $1650^{\circ} \mathrm{C}$ or less

> All of the gangue (mainly $\mathrm{MgAl}_{2} \mathrm{O}_{4}$ spinel) is dissolved

> The metal product is not contaminated (at least not more than usual)

> The viscosity of the slag is as low as possible

> The energy requirement for smelting is as low as possible.

All of the simulations were done at different smelting temperatures with the amounts of reductant and flux as variables. One subset of the results of the modelling is shown here as an example. The case presented in this section of the paper is for a metallurgical-grade chromite ore with highgrade colemanite flux and anthracite. The temperature used in the simulation was $1650^{\circ} \mathrm{C}$. More specific detail on the actual composition of the ore is given in the experimental section of the paper.

Note that the energy requirement was calculated on the basis that the slag, alloy, and gas are all at the same temperature. This is not true for industrial operations, but allows for a relative and consistent comparison between the different cases considered.

Each bar in the three-dimensional plots in Figure 8 is for one discrete simulation. First, the energy requirement for smelting is presented in Figure 8a. As expected, the energy requirement for smelting increases as more flux is used. Note that later in the paper a comparison is made with conventional smelting cases.

In Figure 8b, the amount of undissolved spinel is shown. As expected, higher levels of colemanite result in lower levels of undissolved spinel at low reductant levels. The lowest reductant level is the stoichiometric amount of carbon required for full reduction of all chrome and iron oxide in the ore; the maximum is $50 \%$ more than the stoichiometric amount on a mass basis. Notice that at lower levels of colemanite, the amount of undissolved spinel decreases initially with the amount of reductant, but then increases again. This is due to the reduction of $\mathrm{B}_{2} \mathrm{O}_{3}$ by carbon, which makes the flux ineffective for spinel dissolution. Further evidence of this is in the percentage $\mathrm{Cr}$ and percentage $\mathrm{B}$ recovery to metal (see Figures $8 d$ and $8 f$ ).

Therefore, a careful balance between the amount of reductant, flux, and temperature is required. This is common for normal fluxes $\left(\mathrm{SiO}_{2}\right.$ and $\left.\mathrm{CaO}\right)$, but requires even more attention when borate minerals are used.

Aside from boron contamination of the product, losses due to entrainment can also occur if there is no clear balance

\section{Table IV}

\section{Energy savings for a SAF producing $\mathrm{FeCr}$ (adapted from Ringdalen, 2015)}

\begin{tabular}{l} 
Parameter \\
\hline Lower slag temperature by $100^{\circ} \mathrm{C}$ \\
Preheat raw material by $100^{\circ} \mathrm{C}$ \\
Lower undissolved chromite content in slag by $5 \% \mathrm{Cr}_{2} \mathrm{O}_{3}$ ) \\
Drying wet material from 5 to $2 \%$ moisture \\
Decrease Si in alloy by $2 \%$
\end{tabular}

Saving in energy requirement for smelting 


\section{Fluxing of South African chromite ore with colemanite}

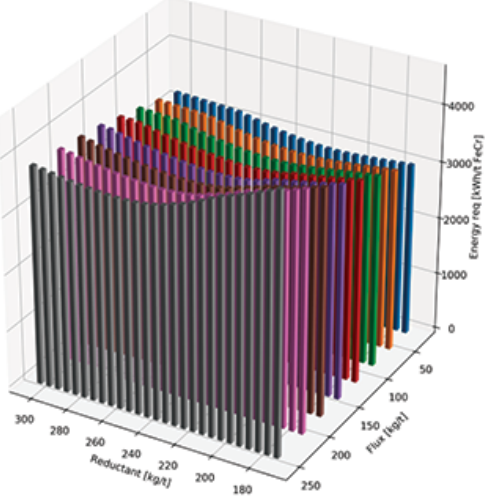

Figure 8a - Energy requirement

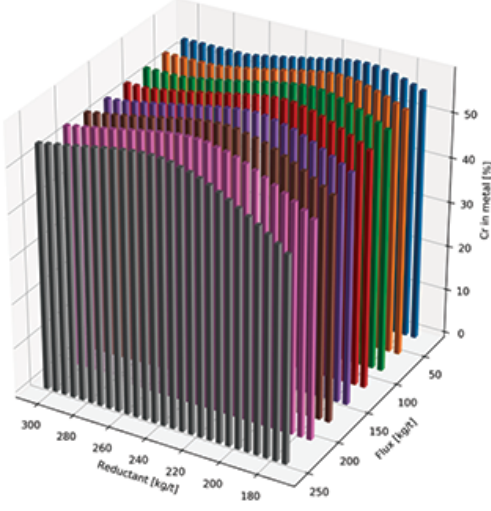

Figure $8 \mathrm{c}-\mathrm{Cr}$ in metal (\%)

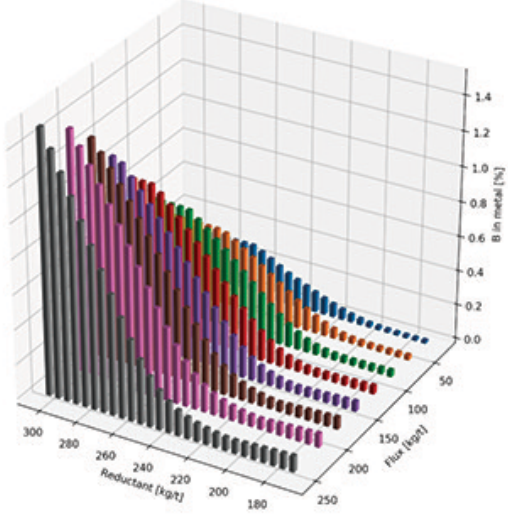

Figure 8e - B in metal (\%)

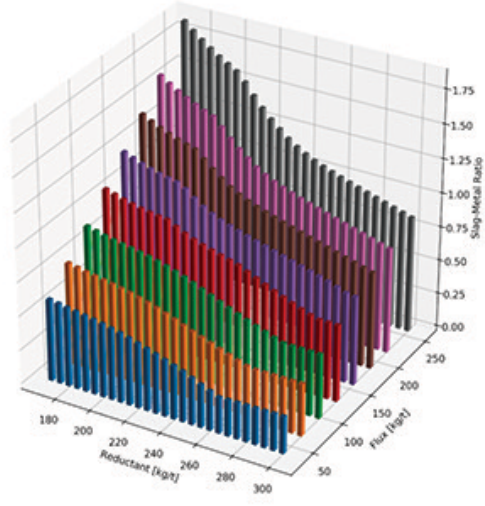

Figure $8 g$ - Slag/metal ratio

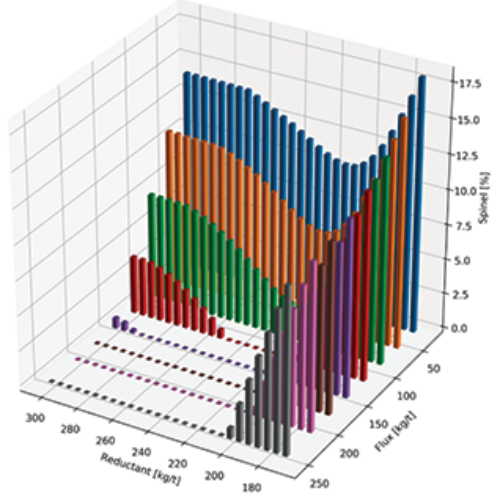

Figure 8b - Undissolved spinel

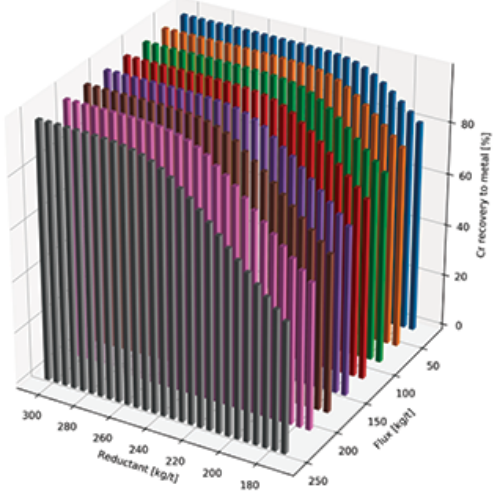

Figure $8 \mathrm{~d}-\mathrm{Cr}$ recovery to metal (\%)

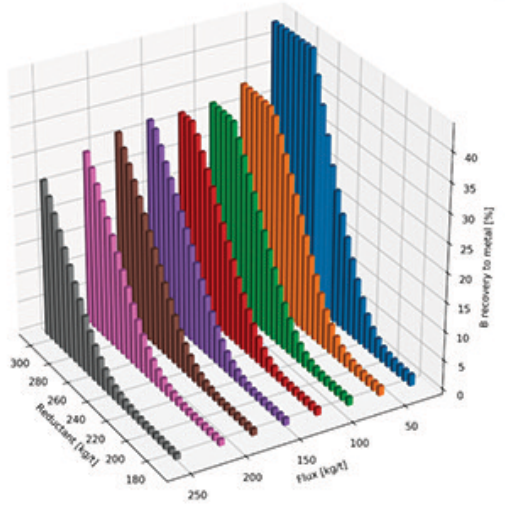

Figure $8 \mathrm{f}-\mathrm{B}$ recovery to metal (\%)

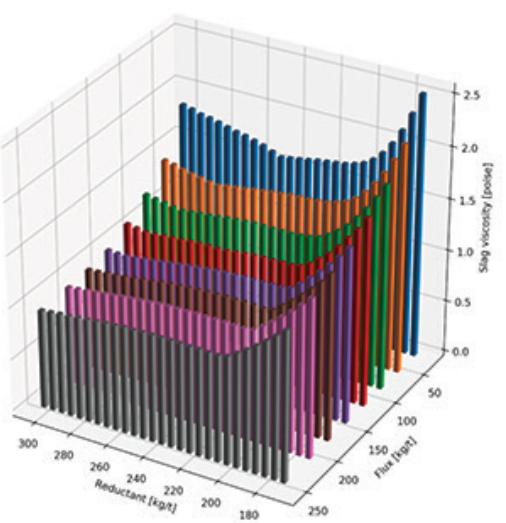

Figure $8 \mathrm{~h}$ - Effective slag viscosity

Figure 8-Thermodynamic modelling results 


\section{Fluxing of South African chromite ore with colemanite}

between carbon and flux addition. In this case, however, all is not lost (see Figure 8h). Despite lower levels of $\mathrm{B}_{2} \mathrm{O}_{3}$ in the slag, $\mathrm{CaO}$ that enters the furnace with colemanite aids in lowering the slag viscosity in almost all cases.

Test work was planned based on all of the modelling results, taking into account all of the factors such as energy consumption, slag viscosity, and possible contamination of the product with boron (with subsequent loss of boron from the slag). The amount of flux added depended on the grade of both the ore and the colemanite sources. Only a small subset of the results is presented in this paper.

\section{Experimental methods}

Overall, laboratory-scale crucible tests were conducted for about 18 months. Various grades of chromite ores, as well as different types of borate minerals, were tested. These included pure $\mathrm{B}_{2} \mathrm{O}_{3}$, various grades of ulexite $\left(\mathrm{NaCaB}_{5} \mathrm{O}_{6}(\mathrm{OH})_{6} .5 \mathrm{H}_{2} \mathrm{O}\right)$, as well as various grades of colemanite. In this paper, only a subset of all of the results is given - that of two grades of both chromite and colemanite. The tests with colemanite were benchmarked against tests with $\mathrm{SiO}_{2}$ only, $\mathrm{B}_{2} \mathrm{O}_{3}$ only, and using conventional smelting regimes.

It is imperative to state that crucible-based test work for smelting has inherent limitations and that larger, pilot-scale testing would be required to assess all of the possible benefits of any of one flux over the others. However, crucible-based test work is of great value for assessing the relative performance of one smelting regime compared to another, since many of the variables can be fixed and the other parameters changed systematically to observe the effect on smelting performance.

\section{Raw materials}

Two chromite ores were tested: one with a high $\mathrm{Cr} / \mathrm{Fe}$ ratio typical for charge chrome production and the other with a low $\mathrm{Cr} / \mathrm{Fe}$ ratio. Only the results for tests using the chromite ore with a high $\mathrm{Cr} / \mathrm{Fe}$ ratio are presented in this paper, as the other results will be given in future publications. Flux materials were reagent-grade $\mathrm{SiO}_{2}, \mathrm{CaO}$, and $\mathrm{B}_{2} \mathrm{O}_{3}$ and two grades of colemanite, referred to here as high-grade colemanite (HGC) and low-grade colemanite (LGC). The reductant in all cases was anthracite sourced locally, which is often used in chromite smelting operations. The compositions of each material are given in Tables V to VII.

\section{Test conditions}

The amount of anthracite required as reductant was calculated on the basis of the total amount of carbon required for full reduction of $\mathrm{Cr}_{2} \mathrm{O}_{3}$ (as $\mathrm{FeCr}_{2} \mathrm{O}_{4}$ and $\mathrm{MgCr}_{2} \mathrm{O}_{4}$ ) and $\mathrm{FeO}_{\mathrm{x}}\left(\mathrm{as} \mathrm{FeCr}_{2} \mathrm{O}_{4}\right.$ and $\mathrm{Fe}_{3} \mathrm{O}_{4}$ ) to $\mathrm{Cr}$ and $\mathrm{Fe}$ respectively. These are termed low-carbon cases (18\% reductant in this case). As reduction of $\mathrm{SiO}_{2}$ and $\mathrm{B}_{2} \mathrm{O}_{3}$ was expected, a set of tests referred to as high-carbon cases was also done, where the amount of anthracite added was 1.5 (i.e. $27 \%$ ) more on a mass basis than the low-carbon case. For the conventional recipe, $25 \%$ of the feed was anthracite.

The amount of flux was based on the amount required to fully dissolve residual $\mathrm{MgAl}_{2} \mathrm{O}_{4}$ in the slag as predicted using the thermochemical calculations done in FactSage, but the amount of HGC was varied between 3 and $9 \%$ to check the sensitivity of the smelting process to varying amounts of flux as compared to the conventional recipe. Fluxes tested were:

$>\mathrm{SiO}_{2}$ only $(10 \%)$

> Varying amounts of pure $\mathrm{B}_{2} \mathrm{O}_{3}(3,4.3,5$, and $8 \%)$

Table $\mathrm{V}$

Normalized, average composition of the ore tested² (mass \%)

\begin{tabular}{|l|c|c|c|c|c|c|c|c|}
\hline Ore & $\mathrm{Cr}_{2} \mathrm{O}_{3}$ & $\mathrm{Al}_{2} \mathrm{O}_{3}$ & $\mathrm{CaO}$ & $\mathrm{FeO}$ & $\mathrm{SiO}_{2}$ & $\mathrm{MgO}$ & $\mathrm{MnO}$ & $\mathrm{TiO}$ \\
\hline High $\mathrm{Cr} / \mathrm{Fe}$ ore & 44.12 & 12.61 & 0.81 & 22.77 & 6.61 & 12.30 & 0.22 & 0.56 \\
\hline
\end{tabular}

Table VI

Normalized, average composition of the borate minerals (mass \%)

\begin{tabular}{|c|c|c|c|c|c|c|c|}
\hline Flux & $\mathrm{CaO}$ & $\mathrm{FeO}$ & $\mathrm{SiO}_{2}$ & $\mathrm{MgO}$ & LOI3 & $\mathrm{B}_{2} \mathrm{O}_{3}$ & $\mathrm{Na}_{2} \mathrm{O}$ \\
\hline $\begin{array}{l}\text { High-grade colemanite } \\
\text { Low-grade colemanite }\end{array}$ & $\begin{array}{l}27.0 \\
26.0\end{array}$ & $\begin{array}{c}0.04 \\
-\end{array}$ & $\begin{array}{c}4.0 \\
13.0\end{array}$ & $\begin{array}{c}3.0 \\
-\end{array}$ & $\begin{array}{c}25.46 \\
34\end{array}$ & $\begin{array}{c}40 \\
27.0\end{array}$ & 0.5 \\
\hline
\end{tabular}

Table VII

Composition of the reductant used for all tests (mass \%)

\begin{tabular}{|c|c|c|c|c|c|c|c|c|c|}
\hline Fixed carbon & Moisture & Volatiles & Ash & $\mathrm{Al}_{2} \mathrm{O}_{3}$ & $\mathrm{CaO}$ & $\mathrm{Fe}_{2} \mathrm{O}_{3}$ & $\mathrm{MgO}$ & $\mathrm{SiO}_{2}$ & $\mathrm{TiO}_{2}$ \\
\hline 80.5 & 1.6 & 6.2 & 11.7 & 2.9 & 0.5 & 0.7 & 0.1 & 5.4 & 0.2 \\
\hline
\end{tabular}




\section{Fluxing of South African chromite ore with colemanite}

> Varying amounts of $\operatorname{HGC}(3,6$, and 9\%)

- A fixed amount of LGC (which would be suitable as per the prediction)

$>\mathrm{CaO}+\mathrm{SiO}_{2}$ (conventional recipe of $9.5 \% \mathrm{SiO}_{2}+7.5 \%$ $\mathrm{CaO})$.

The temperatures selected were $1650^{\circ} \mathrm{C}$ and $1750^{\circ} \mathrm{C}$ for all the tests with borate minerals, and only at $1750^{\circ} \mathrm{C}$ for the conventional recipe.

\section{Furnace set-up and test procedure}

Raw materials were milled in a swing mill after drying at $105^{\circ} \mathrm{C}$ overnight in a muffle furnace. The materials were mixed in small plastic bags after weighing, and the mixtures were placed into either a high-density pure $\mathrm{MgO}$ or a graphite crucible. The charge was compacted mechanically into the crucibles and small holes made in the material bed to enhance the release of gas evolved during testing.

The prepared crucibles were loaded in batches of four into a $30 \mathrm{~kW}$ induction furnace. The four crucibles were placed inside a large graphite crucible, which is used as susceptor inside the water-cooled coil of the induction furnace. The large susceptor is insulated using bubble alumina and an insulating castable material. A graphite lid was placed over the graphite susceptor. A B-type thermocouple was placed through the lid to measure the temperature inside the furnace and argon gas was purged using an alumina lance, also placed through the lid. Additional insulation was provided by a ceramic blanket to avoid excessive radiative heat losses. Furnace power was initially set at $2.5 \mathrm{~kW}$ and increased every 30 minutes by $0.5 \mathrm{~kW}$ until the required test temperature of $1650^{\circ} \mathrm{C}$ or $1750^{\circ} \mathrm{C}$ was reached. The test was left to run at the required temperature for one hour, after which the furnace was switched off and left to cool overnight.

The metal and slag were recovered from the crucibles after breaking the crucibles apart. The slag was not always fully recovered due to attack on the crucible. Where possible, all bulk pieces of metal were collected for weighing. Analysis of metal and slag was by means of ICP-OES for $\mathrm{Cr}, \mathrm{Fe}, \mathrm{Si}, \mathrm{Mn}$, $\mathrm{Ti}$, and $\mathrm{V}$, by LECO for C and S, and ICP-MS for B.

\section{Results and discussion}

\section{Laboratory-scale crucible tests}

Three factors were compared for the smelting tests - the relative amount of bulk alloy that formed, the percentage $\mathrm{Cr}$ in the metal, and main impurity levels, in this case Si and B. The relative amount of bulk alloy formed serves as an indication of the effectiveness of the flux used to facilitate metal-slag separation.

The amount of bulk alloy formed refers to the recoverable lump of alloy that settled at the bottom of the crucible after testing. Metal entrained in the slag phase is often difficult to physically separate and is not, on a laboratory scale, deemed appropriate to compare based on previous experience at Mintek. Since the slag is contaminated with metal in most cases (as will be shown later in this section), the slag analysis was disregarded in all calculations. Consequently, the mass recovery of $\mathrm{Cr}$ was also not calculated. The bulk alloy phase was found to be more homogenous (little entrainment of slag particles found) and hence was used for comparison. For all practical purposes, a comparative study of the quality of the alloy was more suitable, since the recovery of elements in industrial processes is almost always different from that in laboratory tests.

The percentage $\mathrm{Cr}$ in the alloy is compared for the different tests. It is important to realize that the absolute value of $\mathrm{Cr}$ can be affected by the method of analysis. In this project, the standard deviation on the percentage $\mathrm{Cr}$ for the method used was \pm 0.15 .

The level of major impurities plays an important role in the valuing of high-carbon ferrochrome. Any element apart from $\mathrm{Cr}$ is not paid for, and penalties are payable when the material does not meet specification. For comparative purposes, the total Si and B percentages were compared, since these are interdependent. The standard deviations on the analysis errors for Si and B are $\pm 0.1 \%$ and, \pm 10 ppm respectively.

Results are presented in bar-chart format for easy comparison. Where no bar is presented on the chart, the test (or set of tests) failed. Failed tests are tests where no discernible metal and slag phase could be identified and separated due to severe entrainment. These 'failed' tests were repeated at least once to ensure that the result was consistent. Error bars on the charts indicate the standard deviation for the particular quantity. Where there is no error bar, a single test was done for the particular case. The variability of these tests was usually confirmed by a similar case. This was done for two reasons: firstly, so that the test would be more relevant for actual industrial furnace operations, and secondly to limit the number of tests that could be carried out within the budget for this project.

\section{Results of tests using chromite ore with a high $\mathrm{Cr} / \mathrm{Fe}$ ratio}

No separable bulk alloy could be produced at $1650^{\circ} \mathrm{C}$ using the conventional recipe or levels of less than $6 \%$ of either lower- or higher-grade colemanite. The best result achieved, in terms of the amount of metal, was with $4.3 \%$ pure $\mathrm{B}_{2} \mathrm{O}_{3}$. Whether it would be cost-effective to use pure $\mathrm{B}_{2} \mathrm{O}_{3}$ as flux is yet to be explored, as it is even more expensive than colemanite or a combination of conventional fluxes.

The tests at $1750^{\circ} \mathrm{C}$ showed no statistically significant difference between using low- or high-grade colemanite rather than conventional fluxes. Operating at a temperature of $1750^{\circ} \mathrm{C}$ also defeats one of the major aims of the project: operating at lower temperatures.

The amount of alloy formed is not the only parameter that needs to be considered. Grade is assessed by not only the total $\mathrm{Cr}$ in the product, but also by the level of impurities, in this case Si and B, as this would affect the customer downstream.

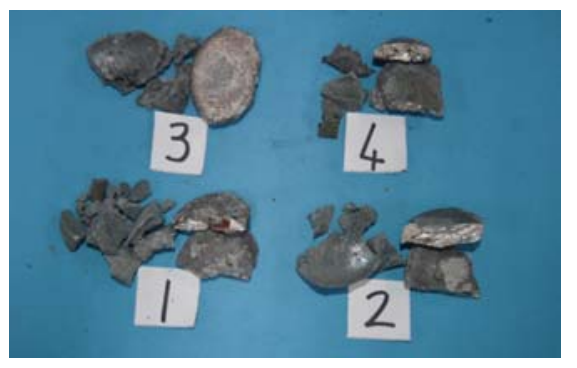

Figure 9-An example of the bulk alloy pellets that form and are collected from a smelting test (bright grey/silver is alloy) 


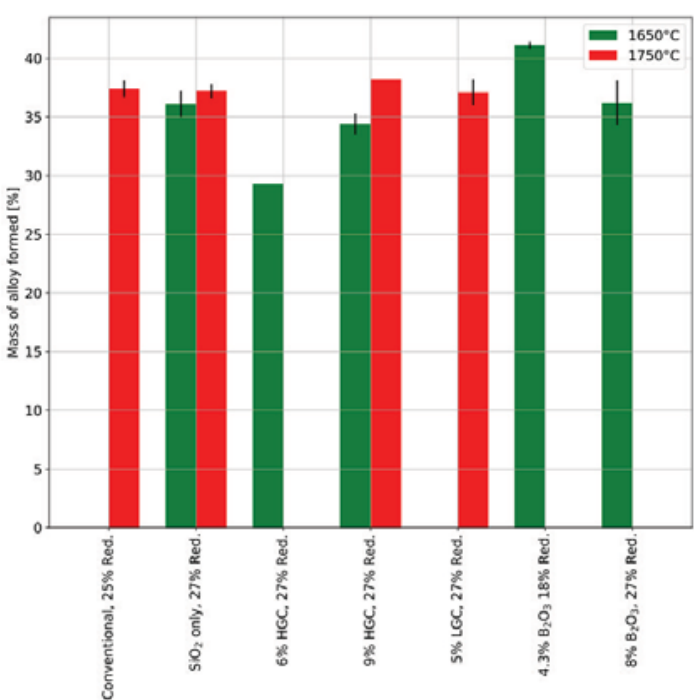

Figure 10-Summary of results (mass of alloy formed) for chromite with high $\mathrm{Cr} / \mathrm{Fe}$ ratio (error bars indicate standard deviation on tests). The percentage values stated refer to the amount of material added as a percentage of the amount of ore added (e.g. ' $6 \%$ HGC, $27 \%$ Red' refers to a case where $6 \mathrm{~g}$ of flux and $27 \mathrm{~g}$ of reductant was added to $100 \mathrm{~g}$ of ore)

The $\mathrm{Cr}$ content of the metal for each of the cases where bulk alloy was formed is shown in Figure 11. In all but one case, the minimum specification for charge chrome $(50 \% \mathrm{Cr})$ was achieved. Just as for the amount of metal formed, it seems that there is no statistically discernible difference when comparing conventional smelting at $1750^{\circ} \mathrm{C}$ and using approximately $9 \%$ high- or $5 \%$ low-grade colemanite at $1650^{\circ} \mathrm{C}$. However, the fact that an alloy can be formed at $1650^{\circ} \mathrm{C}$ using $\mathrm{HGC}$ with this ore is promising, as this implies that the overall operating temperature can be decreased, yielding more-or-less the same result as with conventional fluxes at $1750^{\circ} \mathrm{C}$.

As part of the thermodynamic calculations in FactSage 7.1, the energy requirement for smelting was also calculated. The results are given in Table VIII, along with the expected viscosity of the slag, also calculated using the Viscosity module of FactSage 7.1. Smelting chromite at $1650^{\circ} \mathrm{C}$ with $9 \% \mathrm{HGC}$ would save roughly $3 \%$ on the total energy requirement compared to smelting using conventional fluxes at $1750^{\circ} \mathrm{C}$. The reason that this value is lower than expected is the fact that some $25-30 \%$ by mass of the colemanite is present as crystal water. Calcination of colemanite before use in a furnace would reduce the energy requirement even more. However, if one takes a longer term view, the reduced operating temperature can have significant benefits for a smelter.

Finally, the contamination of the product needs to be quantified. The contents of Si and B, the main impurities in the alloy, are given in Table IX. As expected, less Si is present in tests where borates were used. This could be attributed to two factors - firstly, less $\mathrm{SiO}_{2}$ is present to be reduced in the first place, and secondly, that $\mathrm{B}_{2} \mathrm{O}_{3}$ is preferentially reduced compared with $\mathrm{SiO}_{2}$. The amount of $\mathrm{B}$ present in the alloy is higher at $1750^{\circ} \mathrm{C}$ than $1650^{\circ} \mathrm{C}$, which was also expected.

One question remains regarding boron contamination of the alloy. There is no formal boron specification for $\mathrm{HCFeCr}$ that the authors could find in any standard or literature. However, during the production of stainless steel, there might be a very tight specification on the amount of boron present.

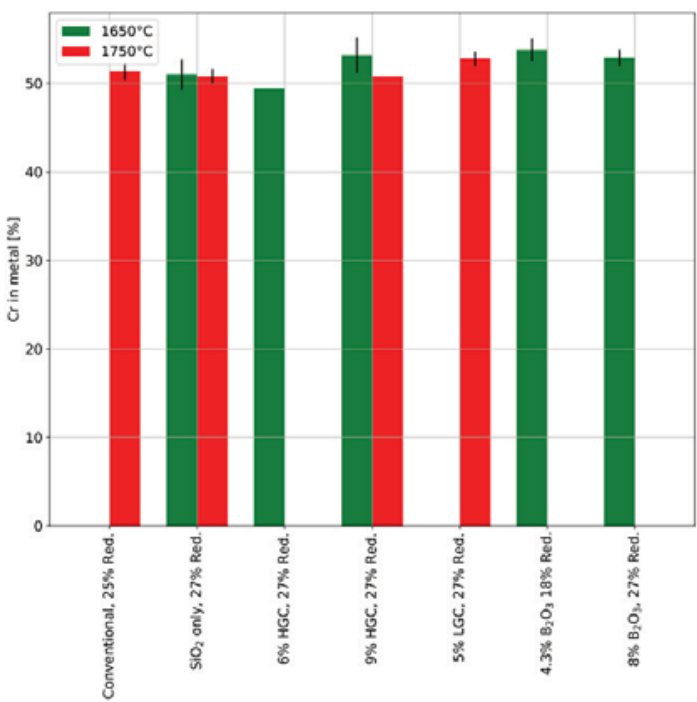

Figure 11-Summary of results (Cr grade) for chromite with high $\mathrm{Cr} / \mathrm{Fe}$ ratio (error bars indicate standard deviation on tests)

Table IX

Impurity levels for alloy formed from chromite with a high $\mathrm{Cr} / \mathrm{Fe}$ ratio

\begin{tabular}{|c|c|c|c|c|}
\hline \multirow[t]{2}{*}{ Fluxing regime } & \multicolumn{2}{|c|}{$T=1650^{\circ} \mathrm{C}$} & \multicolumn{2}{|c|}{$T=1750^{\circ} \mathrm{C}$} \\
\hline & $\% S i$ (土SD) & $\% \mathrm{~B}$ (土SD) & $\% S i$ (土SD) & $\% \mathrm{~B}( \pm \mathrm{SD})$ \\
\hline $\begin{array}{l}\text { Conventional } \\
\mathrm{SiO}_{2} \text { only } \\
6 \% \mathrm{HGC} \\
9 \% \mathrm{HGC} \\
5 \% \text { LGC }\end{array}$ & $\begin{array}{c}- \\
5.38 \pm 1.47 \\
1.26 \pm 0.07 \\
2.98 \\
-\end{array}$ & $\begin{array}{c}- \\
- \\
- \\
1.21 \\
-\end{array}$ & $\begin{array}{c}1.03 \pm 0.22 \\
7.71 \pm 0.8 \\
- \\
3.1 \\
1.8 \pm 0.6\end{array}$ & $\begin{array}{c}- \\
- \\
- \\
4.9 \\
0.18 \pm 0.01\end{array}$ \\
\hline
\end{tabular}

Table VIII

Theoretical slag viscosities and energy requirements for smelting

\begin{tabular}{|l|c|c|c|c|}
\hline \multirow{2}{*}{ Fluxing regime } & \multicolumn{2}{|c|}{$1650^{\circ} \mathrm{C}$} & \multicolumn{2}{|c|}{$1750^{\circ} \mathrm{C}$} \\
\cline { 2 - 5 } & Slag viscosity (poise) & Energy requirement (MWh/t FeCr) & Slag viscosity (poise) & Energy requirement (MWh/t FeCr) \\
\hline Conventional & 1.8 & 3.15 & 1.7 & 1.8 \\
$\mathrm{SiO}_{2}$ only & 2.7 & 3.29 & 0.9 & 3.45 \\
$6 \%$ HGC & 1.5 & 3.27 & 3.6 & 3.60 \\
$9 \%$ HGC & 1.3 & 3.33 & 3.1 & 3.58 \\
$5 \%$ LGC & 1.8 & 3.25 & \\
\hline
\end{tabular}




\section{Fluxing of South African chromite ore with colemanite}

This is beyond the scope of this particular paper, and is being investigated. The authors have done some initial tests on converting of HCFeCr with the aim of boron removal.

The full details of the decarburization test work are not given here, since the results need to be confirmed. In brief, a sample of ferrochrome metal produced during testing was decarburized in an alumina crucible in an induction furnace. An alumina lance was used to inject pure oxygen into the melt. A synthetic slag of $40 \% \mathrm{CaO}-40 \% \mathrm{SiO}_{2}-10 \% \mathrm{MgO}$ and $10 \% \mathrm{Al}_{2} \mathrm{O}_{3}$ was added to the melt periodically to aid the converting process. A temperature of $1600^{\circ} \mathrm{C}$ was maintained. Samples were taken and analysed using ICP (for metal components) and LECO for $\mathrm{C}$. The initial and final composition of the alloy sample is given in Table $\mathrm{X}$.

A plot of the boron content as a function of time (Figure 12) shows that boron removal follows an exponential, rather than linear, relationship, indicating possible first-order kinetics for removal. After 32 minutes of blowing time, the boron content of the melt was reduced to $25 \%$ of the original value, showing that removal of boron from the melt is indeed possible. A side effect of this process is the increased concentration of impurities such as $P$, which will have to be removed in a later stage of blowing or a separate process step. This implies that steelmakers would necessarily have to adjust parameters in their operations when using boroncontaining ferrochrome.

\section{Conclusions and future work}

Fluxing of chromite ore with borate ores shows promise, but many factors need to be taken into account to gain maximum benefit from it. Results from laboratory tests show that it is indeed possible to reduce operating temperatures from $1750^{\circ} \mathrm{C}$ to $1650^{\circ} \mathrm{C}$ using colemanite in place of conventional fluxes. The amount and grade of alloy formed when using colemanite as flux at $1650^{\circ} \mathrm{C}$ was more-or-less the same as in the conventional smelting case at $1750^{\circ} \mathrm{C}$. In some cases (e.g.

Table $X$
Initial and final composition of the alloy melt
subjected to decarburization using pure oxygen
\begin{tabular}{|l|c|c|c|c|c|c|c|c|}
\hline $\mathbf{t}(\mathbf{m i n})$ & $\mathbf{C r}(\%)$ & $\mathbf{S i}(\%)$ & $\mathbf{M n}(\%)$ & $\mathbf{F e}(\%)$ & $\mathbf{P}(\%)$ & $\mathbf{B}(\mathbf{p p m})$ & $\mathbf{C r}(\%)$ & $\mathbf{T i}(\%)$ \\
\hline 0 & 8.54 & 1.23 & 0.27 & 44.3 & 0.04 & 1815 & 46.2 & 0.27 \\
32 & 7.32 & 0.63 & 0.23 & 48.0 & 0.20 & 480 & 48.7 & 0.21 \\
\hline
\end{tabular}

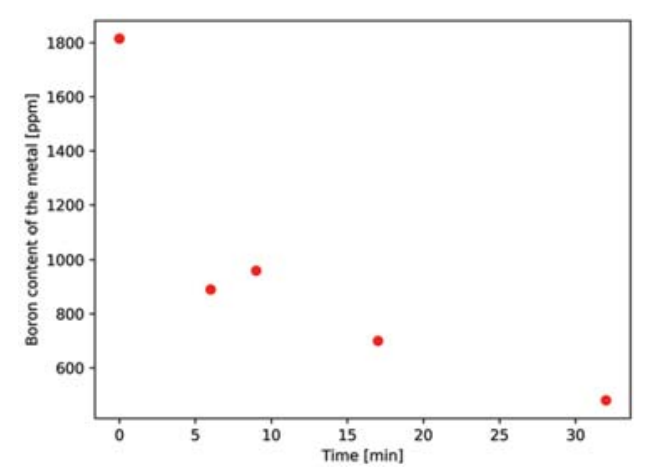

Figure $12-$ Boron removal from a ferrochrome alloy at $1600^{\circ} \mathrm{C}$ in contact with a synthetic slag with pure $\mathrm{B}_{2} \mathrm{O}_{3}$ as flux) it was found that the grade of the alloy was increased by some $1-2 \% \mathrm{Cr}$, which implies that some more test work with borates is required to obtain a full picture of the potential benefits. Boron contamination of up to $1 \%$ could be a problem, but it seems that boron removal might be possible and this should be studied in more detail.

Furthermore, tests need to be conducted at pilot scale in a longer term campaign to confirm the results found at the laboratory scale. This is especially important to determine the optimal level of flux and reductant relevant to furnace operations and investigate other factors, such as the conductivity of the slag, when $\mathrm{B}_{2} \mathrm{O}_{3}$ is present. The ultimate success of colemanite as a flux will depend greatly on the relative cost of flux balanced against the short- and longer term benefits realized, especially since conventional fluxes are cheap and are sourced locally, while borates would have to be sourced from, for example, Turkey.

\section{Acknowledgements}

This paper is published by permission of Mintek. The authors would like to thank Mintek, ERAMIN, and the South African Department of Science and Technology for sponsoring the work. The contributions of our colleagues are gratefully acknowledged.

Finally, the authors wish to thank the partners of the BOFLUX consortium (Ab Etiproducts Oy, Finland and Siyanda Chrome Company Pty Ltd) for their support with material and in-depth discussions during the project without them, this project would not have been possible. Mintek also acknowledges the support of NIPMO in the ongoing maintenance of its IP portfolio.

\section{References}

AKвеrdin, A., Kim, A.S., Ilmaz, O., Isletmeleri, G., and Zhuckov, V. 2013. Boron in ferroalloy production. INFACON XIII, Proceedings of the Thirteenth International Ferroalloys Congress, Almaty, Kazakhstan. pp. 325-334. http://www.pyrometallurgy.co.za/InfaconXIII/0325-Akberdin.pdf

EuRopeAn COMmission. 2014. http://eur-lex.europa.eu/legal-content/EN/TXT/ PDF/?uri=CELEX:52014DC0297\&from=EN [accessed 12 February 2018].

CRAmer, L., BASSON, J., and NeLSON, L. 2004. The impact of platinum production from UG2 ore on ferrochrome production in South Africa. Journal of the South African Institute of Mining and Metallurgy, vol. 104, no. 9. pp. 517-527.

GASIK, M. 2013. Handbook of Ferroalloys: Theory and Technology. Elsevier, Waltham, USA.

CRYSTALLOGRAPHY 365. 2014. https://crystallography365.wordpress.com/ 2014/09/24/the-worlds-most-underappreciated-gemstone-red-spinel/

GeldenhuYs, I. 2013. Aspects of DC chromite smelting at Mintek: An overview. INFACON XIII. Proceedings of the Thirteenth International Ferroalloys Congress, Almaty, Kazakhstan. pp. 31-47.

HAYES, P. 2004. Aspects of SAF smelting of ferrochrome. INFACON X: Proceedings of the Tenth International Ferroalloys Congress, Cape Town, South Africa. Southern African Institute of Mining and Metallurgy, Johannesburg. pp. 1-14.

HolAPPA, L. and XIAO, Y. 2004. Slags in ferroalloys production - review of present knowledge. Journal of the South African Institute of Mining and Metallurgy, vol. 104, no. 7. pp. 429-438.

Jones, R.T. and ERwEe, M.W. 2016. Simulation of ferro-alloy smelting in DC arc furnaces using Pyrosim and FactSage. Calphad, vol. 55. pp. 20-25.

PARISER, H. 2017. Re-positioning South Africa. Proceedings of the SAIMM Chrome Colloquium, Mintek, Randburg, South Africa, 19-20 June 2017. Southern African Institute of Mining and Metallurgy, Johannesburg.

RINGDALEN, E.R. 2015, Energy consumption during HCFeCr-production at Ferbasa. INFACON XIV. Proceedings of the Sixteenth International Ferroalloys Congress, Kiev, Ukraine. pp. 668-675.

WaClaWSKA, I. 1988. Thermal decomposition of colemanite. Thermochimica Acta, vol. 126. pp. 307-318. 